\title{
Spectrophotometric Determination Of Nitrazepam And Dapson Using Vanillin Reagent in Pharmaceutical Preparations
}

\author{
Maha T. Al-Obaidi Theia'a N. Al-Sabha \\ Thabit S. Al-Ghabsha \\ Department of Chemistry / College of Education \\ University of Mosul
}

Received

23 / $06 / 2013$
Accepted

04 / 09 / 2013

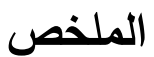

تم وصف طريقة طيفية بسيطة وحساسة وانتقائية لتقدير الدابسون والنايترازيبام في الحالة

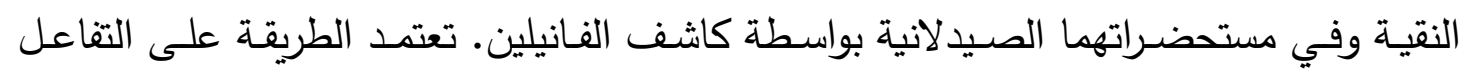

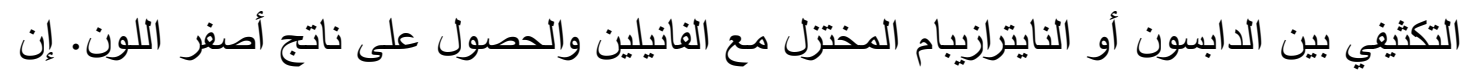
قاعدة شيف الناتجة تمتلك أقصى امتصاص عند الطول الموجي 405 نانوميتر لكلا الدوائين.

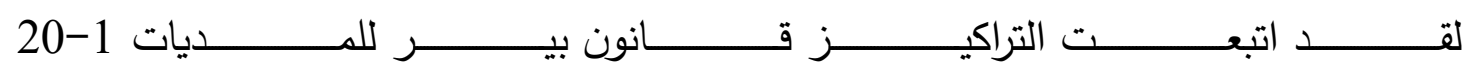

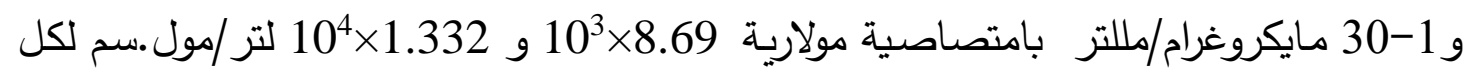
من الدابسون والنايترازيبام على التوالي. كما وجد حد الكثف والحد الكمي 0.087 و 0.069 مـايكروغرام/مللتر للدابسـون على التوالي في حين وجد 0.069 و 0.231 مـايكروغرام/مللتر للنايترازيبام على التوالي. أظهرت الطريقة دقة وتوافق جيدين وأمكن تطبيقها في تقدير الدوائين

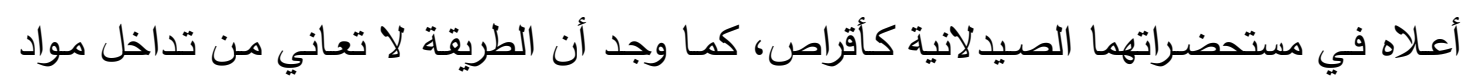

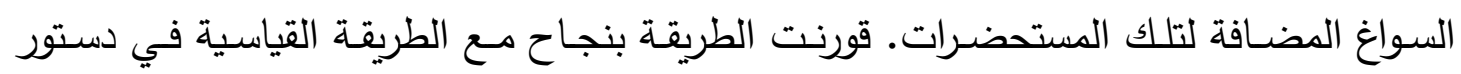

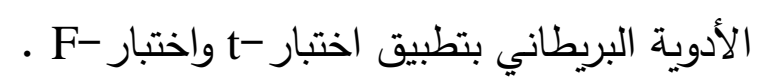

\section{Abstract}

A simple, sensitive and selective spectrophotometric method is described for the determination of dapson and nitrazepam in bulk drug and in dosage forms using vanillin as the chromogenic agent. The method is based on the condensation reaction between dapson (DN) and reduced nitrazepam (RNZ) with vanillin to produce an intense yellow colored product. The resulting Schiff's bases show an absorption maximum at 
$405 \mathrm{~nm}$ for both drugs. Beer's law was obeyed in the concentration range $1-30$ and $1-20 \mu \mathrm{g} / \mathrm{ml}$ with a molar absorptivity of $8.69 \times 10^{3}$ and $1.332 \times 10^{4}$ $\mathrm{L} \mathrm{mol}^{-1} \mathrm{~cm}^{-1}$ for DN and RNZ respectively. The limit of detection (LOD) and limit of quantification (LOQ) were found to be 0.087 and 0.299 $\mu \mathrm{g} / \mathrm{ml}$ for $\mathrm{DN}$, respectively and 0.069 and $0.231 \mu \mathrm{g} / \mathrm{ml}$ for RNZ, respectively. The method shows good accuracy and precision, and was applied successfully to the determination of DN and RNZ in tablets. No interference was observed from common additives found in pharmaceutical preparations. The results obtained by the proposed method were validated statistically by comparing the results with those of official methods by applying the Student's t-test and F-test.

Key words: Schiff's base, Vanillin, Dapson, Nitrazepam.

\section{Introduction}

Nitrazepam (NZ) chemically known as 7-nitro-5-phenyl-1,3dihydro-2h-1,4-benzodiazepine-2-one (Figure 1) is a hypotic agent that belongs to the benzodiapine class. NZ used in the treatment of insomnioe which has sedative and motor impairing properties [1], as well as anxiolytic, amnestic, anticovulsant and skeletal muscle relaxant properties, and it has been used in the treatment of stress related disorders [2].

Dapsone (DN) chemically known as 4,4-diaminodiphenyl sulfone (Figure 1) is antileprotic drug used into the treatment of paubacillary leprosy $[3,4]$.<smiles>O=C1CN=C(c2ccccc2)c2cc([N+](=O)[O-])ccc2N1</smiles>

Nitrazepam

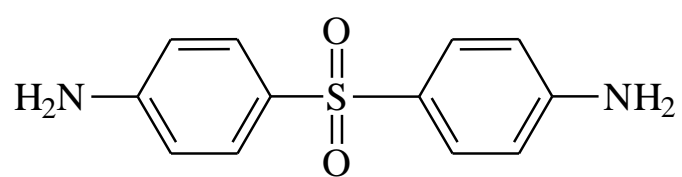

$\mathrm{MWt}=248.302 \mathrm{~g} / \mathrm{ml}$

Dapsone

Figure 1 : Chemical structures of $\mathrm{DN}$ and $\mathrm{NZ}$

Various analytical techniques have reported for the determination of DN and NZ drugs such as chromatography [5-8], voltammetry [9-10], fluorimetry [11] and chemiluminescence [12].

Spectrophotometric methods are still considered to be a very convenient and cost-effective technique and hence widely used for the determination of these drugs in pure and in pharmaceutical preparations, various spectrophotometric methods have been reported for determination 
of $\mathrm{NZ}$, after reduction by $\mathrm{Zn} / \mathrm{HCl}$, and $\mathrm{DN}$ such as coupling of the diazotized NZ and DN with different reagents namely acetyl acetone, diphenylamine and citrazinic acid [13], resorcinol [14], N-(1-napthyl) ethylenediamine dihydrochloride [15], orcinol [16], benzoylacetone [17], phloroglucinol [18], N,N-diethyl-p-phenylenediamine sulphate [19] and m-aminophenol [20]. Metol was used as $\pi$-acceptor to form charge transfer complex with reduced $\mathrm{NZ}$ as n-donor [21]. pDimethylaminocinnamaldehyde forming Schiff's bases complex with DN in acidic medium [22]. 9-Chloroacridine[23] and sodium 1,2naphthoquinone-4-sulfonic [24] as chromogenic reagents were used for determination of dapsone.

The present investigation method is development of simple and sensitive spectrophotometric method for the estimation of DN and NZ in both pure and in pharmaceutical preparations as tablet based on the condensation reaction between $\mathrm{DN}$ and $\mathrm{NZ}$ with vanillin as the chromogenic agent in acidic medium to form Schiff's base products.

\section{Experimental}

\section{Apparatus}

Shimadzu UV-1800 PC UV-Visible spectrophotometer equipped with a 1.0-cm path length silica cell, Philips PW (9421) pH-meter with a combined glass electrode was used for $\mathrm{pH}$ measurements. All calculations in the computing process were performed in Microsoft Excel for Windows.

\section{Chemicals}

All reagents were of analytical-reagent grade which were provided by BDH and Fluka companies.

Working standard solution $\mathrm{DN}\left(100 \mu \mathrm{g} . \mathrm{ml}^{-1}\right)$ is prepare by dissolving $0.01 \mathrm{~g}$ of pure material in few mls of ethanol and diluted to the mark in a $100 \mathrm{ml}$ volumetric flask with distilled water. The solution was kept in refrigerator.

Working standard solution of RNZ (100 $\boldsymbol{\mu g}^{\mathrm{m}} \mathrm{ml}^{-1}$ ) Accurately $50 \mathrm{mg}$ of $\mathrm{NZ}$ was weighed into a separate $100 \mathrm{ml}$ beaker and dissolved $\mathrm{NZ}$ in $20 \mathrm{ml}$ absolute ethanol with heating. To this $5 \mathrm{ml}$ conc. hydrochloric acid and $1 \mathrm{~g}$ of zinc dust were added and shaken thoroughly for about $15 \mathrm{~min}$ and then diluted up to the mark with water in a $100 \mathrm{ml}$ standard flasks $(500 \mu \mathrm{g}$ $\mathrm{ml}^{-1}$ ), and filter through Whatmann no.41 filter paper, then $20 \mathrm{ml}$ from this solution was neutralized with $20 \%$ sodium carbonate solution to $\mathrm{pH} 6$ and filtered using sintered glass crucible No.2, then diluted with water in $100 \mathrm{ml}$ standard flask to obtain $100 \mu \mathrm{g} \mathrm{ml}^{-1}$.

Vanillin Reagent (10\%) is prepared by dissolving 10g of 4-hydroxy-3methoxy benzaldehyde in $100 \mathrm{ml}$ absolute ethanol in a volumetric flask. 
Sulphuric acid solution ( $(0.1 \mathrm{M})$ is prepared by diluting of a suitable volume of conc. $\mathrm{H}_{2} \mathrm{SO}_{4}$ to $100 \mathrm{ml}$ with distilled water in a volumetric flask.

Nitric acid solution( $(0.1 \mathrm{M})$ is prepared by diluting of a suitable volume of conc. $\mathrm{HNO}_{3}$ to $100 \mathrm{ml}$ with distilled water in a volumetric flask.

\section{Recommended procedure}

Aliquots of the working solution of DN (1-20 $\left.\mu \mathrm{g} \cdot \mathrm{ml}^{-1}\right)$ and RNZ (1-30 $\left.\mu \mathrm{g} \cdot \mathrm{ml}^{-1}\right)$ were transferred into separate series of $5 \mathrm{ml}$ calibrated flasks. Then, $2 \mathrm{ml}$ of $10 \%$ vanillin and $1.5 \mathrm{ml}$ of $0.1 \mathrm{M} \mathrm{H}_{2} \mathrm{SO}_{4}$ for DN and $1 \mathrm{ml}$ of $0.1 \mathrm{M} \mathrm{HNO}_{3}$ for RNZ were added. The solutions were diluted to the mark with distilled water and kept at room temperature $\left(20^{\circ} \mathrm{C}\right)$ for 15 and $5 \mathrm{~min}$ for DA and RNZ, respectively. The absorbance was measured at $405 \mathrm{~nm}$ against reagent blank.

\section{Procedure for DN tablets:}

Ten tablets were powdered and mixed thoroughly. An amount of powder equivalent to $10 \mathrm{mg}$ of $\mathrm{DN}$ was weighed into a $100 \mathrm{ml}$ calibrated flask and dissolved in $10 \mathrm{ml}$ water-ethanol $(50: 50 \mathrm{v} / \mathrm{v})$ mixture and was shaken for $10 \mathrm{~min}$, then filtered through Whatman no. 41 filter paper and the volume was made up to the mark with distilled water to obtain 100 $\mu \mathrm{g} / \mathrm{ml} \mathrm{DN}$ and subjected to analysis following the procedure described above.

\section{Procedure for NZ tablets:}

Ten tablets (5 mg each) were emptied, pulverized. A quantity of the powder equivalent to $25 \mathrm{mg}$ of $\mathrm{NZ}$ was weighed accurately and dissolved in $10 \mathrm{ml}$ ethanol into a separate $50 \mathrm{ml}$ calibrated flask. Then, 5 $\mathrm{ml}$ of conc. hydrochloric acid and $1 \mathrm{~g}$ of zinc dust were added and shaken thoroughly for about $30 \mathrm{~min}$. The volume was diluted to the mark with distilled water, mixed well and filtered using a Whatmann no.41 filter paper and $20 \mathrm{ml}$ from this solution was neutralize with $20 \%$ sodium carbonate solution to $\mathrm{pH} 6$ and filtered using sintered glass crucible No.2, then diluted with water in $100 \mathrm{ml}$ calibrated flask to obtain $100 \mu \mathrm{g} \cdot \mathrm{ml}^{-1}$

\section{RESULTS AND DISCUSSION: \\ Chemistry}

The Schiff's base linkages are form by a condensation reaction of aromatic amine with an aldehyde group at the terminus of an organic compound [25]. Based on this reaction many pharmaceutical compounds containing aromatic amine group have been determined [26-30] and the same reaction was adopted for the assay of DN and NZ (after reduction), since they contain primary aromatic amine group. The proposed method 
utilized vanillin which contains an aldehyde group. The condensation reaction requires the presence of an acid for the protonation of the carbonyl oxygen and thereby leaving the carbonyl carbon fully positive charge. The $\mathrm{NH}_{2}$ group in $\mathrm{DN}$ and $\mathrm{RNZ}$ donates a lone pair of electrons to the carbon present in the carbonyl group of vanillin. Internal rearrangement thereafter results in the formation of imine (Schiff's base) and then giving water and proton as by-products [25]. The tentative reaction scheme is shown in Scheme 1.

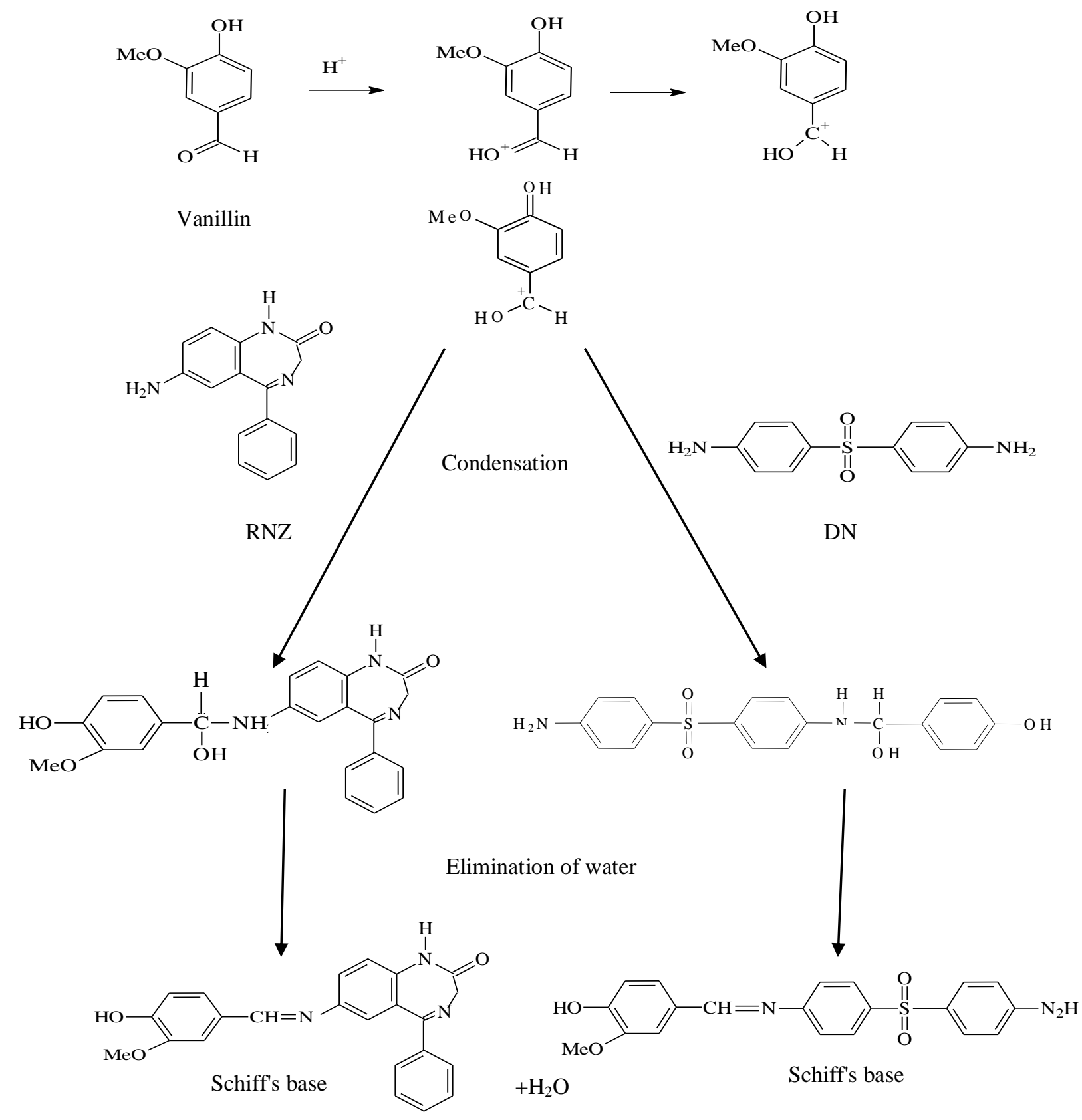

Scheme1. Probable mechanism of the Schiff bases formation reaction between DN and RNZ with vanillin reagent

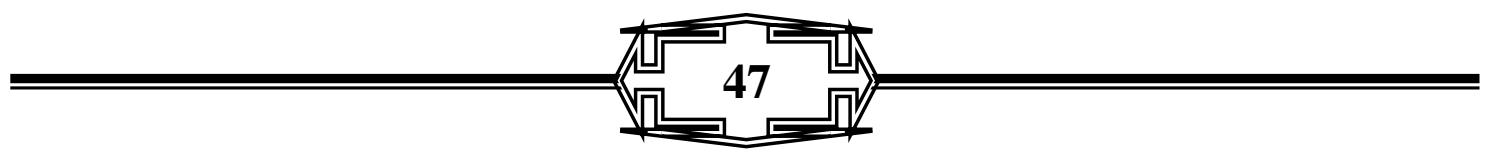




\section{Spectral characteristics}

The proposed method involves the reaction of DN and RNZ with vanillin reagent in acidic medium and forming a yellow colored Schiff's base products having maximum absorption at $405 \mathrm{~nm}$. This wavelength was used for all subsequent measurements. The absorption spectra of the reaction product are shown in Figure 2. The corresponding reagent blank have no absorbance at this wavelength.

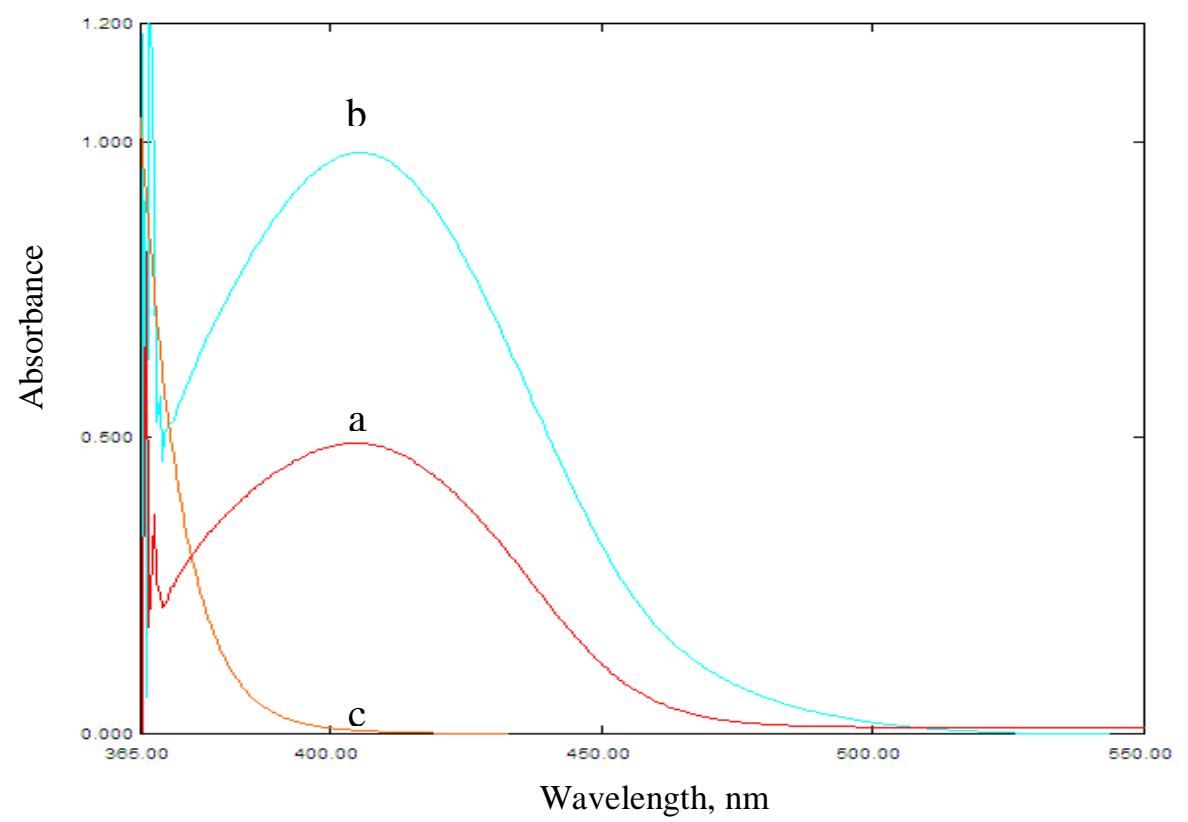

Figure 2: Absorption spectra of (a) DN $\left(14 \mu \mathrm{g} \cdot \mathrm{ml}^{-1}\right)$, (b) RNZ $\left(18 \mu \mathrm{g} \cdot \mathrm{ml}^{-1}\right)$ products with vanillin (10\%) against reagent blank and (c) Reagent blank against distilled water under the optimum conditions

\section{Optimization of conditions}

The optimum conditions for the color development of the products were established by varying the parameters one at a time, keeping the others fixed and observing the effect produced on the absorbance of colored species. The following experiments were conducted for this purpose and conditions so obtained were incorporated in general procedure.

\section{Effect of solvents}

Vanillin is insoluble in water but soluble in organic solvent, therefore; methanol, ethanol, acetonitrile, acetone and 1,4-dioxane were used as solvent for vanillin and for final dilution have been examined in order to achieve maximum sensitivity and products stability, As shown in Table1, It was found that on using methanol as solvent for the vanillin, and dilution with water, for both drugs, were gave maximum color intensity. So; this system of solvents has been recommended in this method. 
Maha T. Al-Obaidi \& Theia'a N. Al-Sabha \& Thabit S. Al-Ghabsha

Table 1: Effect of solvents on absorbance of drugs-vanillin products

\begin{tabular}{|ccccccc|}
\hline DN or RNZ & Vanillin & Dilution & \multicolumn{2}{c|}{ DN } & \multicolumn{2}{c|}{ RNZ } \\
\cline { 4 - 7 } Dissolved in & Dissolved in & by & $\boldsymbol{\lambda}_{\max }(\mathbf{n m})$ & Absorbance & $\boldsymbol{\lambda}_{\max }(\mathbf{n m})$ & Absorbance \\
\hline Water & Methanol & Water & 405 & 0.194 & 405 & 0.132 \\
Water & Methanol & Methanol & 401 & 0.090 & 405 & 0.128 \\
Water & Ethanol & Water & 405 & 0.149 & 404.5 & 0.110 \\
Water & Ethanol & Ethanol & 403 & 0.042 & 408 & 0.085 \\
Water & Water & Water & 403.5 & 0.068 & 402 & 0.095 \\
Water & Acetone & Acetone & 403.5 & 0.022 & 403 & 0.068 \\
Water & Acetonitrile & Water & 402 & 0.129 & 402 & 0.107 \\
Water & Acetonitrile & Acetonitrile & 369 & 0.059 & 401 & 0.105 \\
Water & 1,4-Dioxane & Water & 404.5 & 0.079 & 402 & 0.111 \\
Water & 1,4-Dioxane & 1,4-Dioxane & 410 & 0.024 & 399 & 0.106 \\
\hline
\end{tabular}

\section{Effect of vanillin concentration}

The effect of vanillin on the sensitivity of its reaction with DN and RNZ was studied by using $10 \%$ vanillin and it was observed that when 2 $\mathrm{ml}$ was used, the absorbance readings were nearly constant with high sensitivity for both drugs; below and above this volume there was a decrease in absorbance (Fig. 3). Hence, $2 \mathrm{ml}$ of $10 \%$ vanillin was used as optimum in a total volume of $5 \mathrm{ml}$.

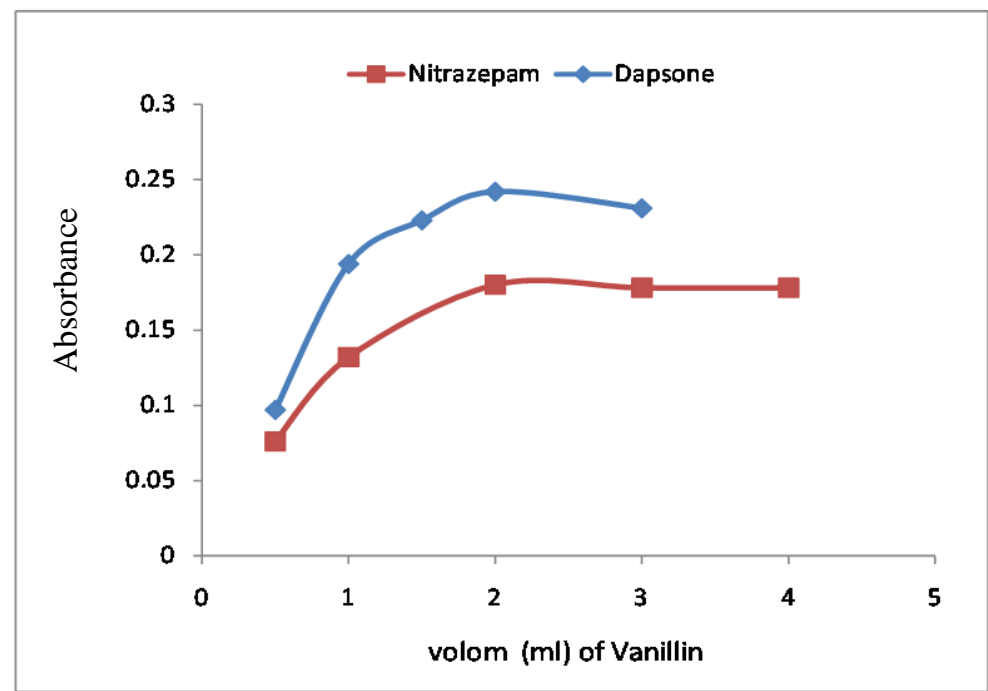

Figure 3: Effect of vanillin reagent concentration on the absorption

\section{Effect of $\mathrm{pH}$ and acids}

The condensation reaction of vanillin with DN and RNZ are formed with low sensitivity in the absence of acid with $\mathrm{pH} 6.13$, but gave high sensitivity in acidic medium with $\mathrm{pH} 0.77$ in the presence of $0.1 \mathrm{M}$ $\mathrm{HCl}$, therefore; the effect of different acids, nitric acid, phosphoric acid, sulphuric acid acetic acid and formic acid with $0.1 \mathrm{M}$ concentration were examined. As seen in Fig. 4, the maximum absorbance value was obtained in the presence of sulphuric acid and nitric acid for DN and RNZ respectively. The amount of these acids are studied and found $1.5-2.0 \mathrm{ml}$ 
of $0.1 \mathrm{M}$ sulphuric acid and nitric acid gave high coloured products for DN and RNZ respectively, and beyond this amounts, the absorbance would be decreased, (Fig. 5). However $1.5 \mathrm{ml}$ for DN and $1 \mathrm{ml}$ for RNZ were chosen as optimum amounts in this method.

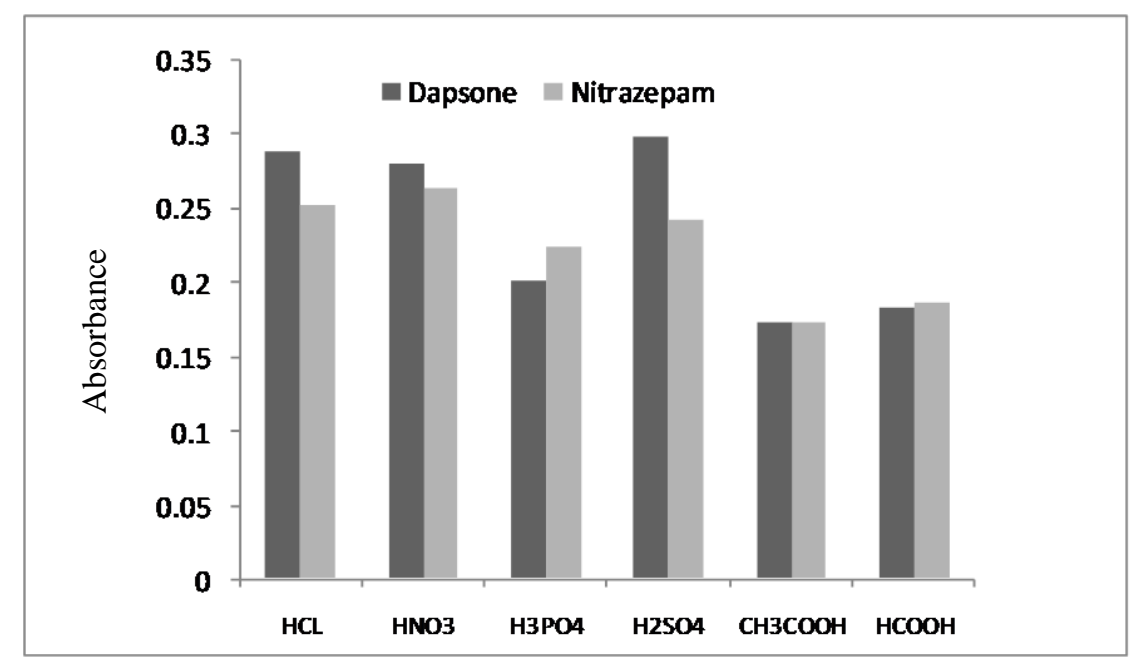

Figure 4. Effect of acids on the absorption of vanillin products with DN and RNZ

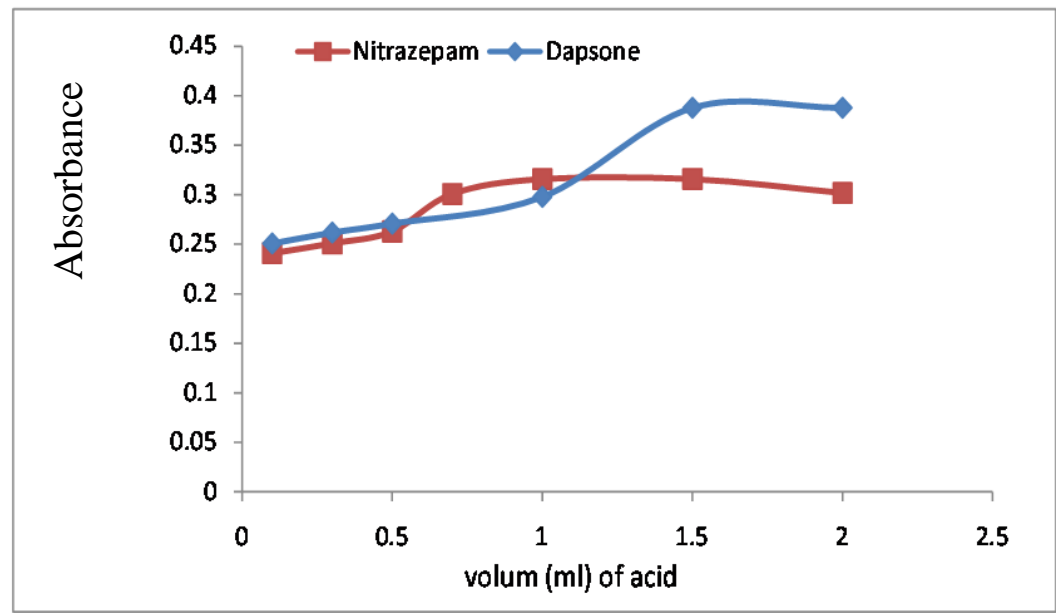

Figure 5. Effect of $\mathrm{H}_{2} \mathrm{SO}_{4}$ and $\mathrm{HNO}_{3}$ on the absorption of vanillin products with DN and RNZ respectively

\section{Effect of temperature and reaction time}

The reaction time was determined by following the color development at room temperature $\left(23^{\circ} \mathrm{C}\right)$ and at $40^{\circ} \mathrm{C}$. The absorbance was measured at 5 and 10 minutes intervals against reagent blank treated similarly. it was found that the color products show maximum absorbance after 15 and $5 \mathrm{~min}$ at room temperature and were stable for further 25 and 35 min for DN and RNZ respectively, (Fig.6). At $40^{\circ} \mathrm{C}$, the absorbance decreases, indicating dissociation. Hence, 20 and $10 \mathrm{~min}$ at room temperature are recommended for the proposed method. 


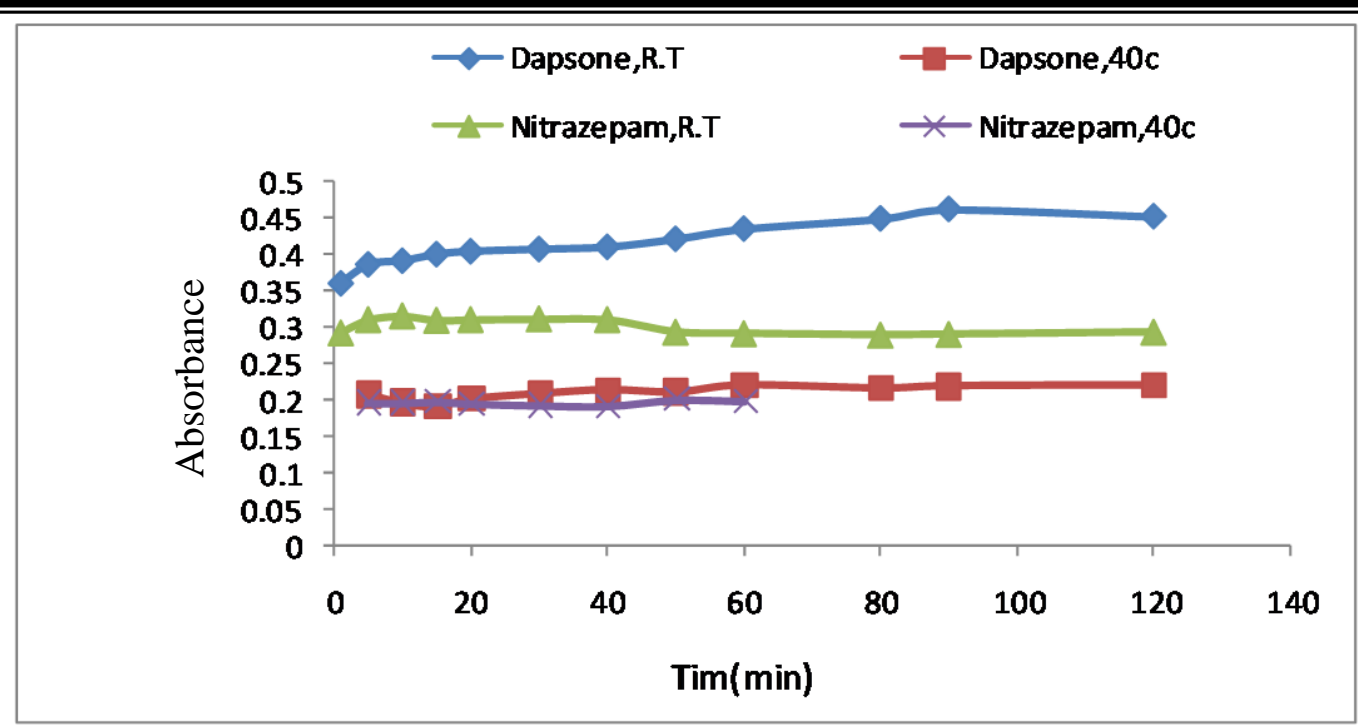

Figure 6. Effect of temperature on the absorbance of $10 \mu \mathrm{g} \cdot \mathrm{ml}^{-1} \mathrm{DN}$ and $6 \mu \mathrm{g} \cdot \mathrm{ml}^{-1} \mathrm{RNZ}$ with vanillin

\section{Order of addition}

The order of addition of reactants on the color development was examined After optimizing all other experimental variables. Maximum sensitivity was achieved when drug and vanillin were added before adding the acid. Hence, the method was performed in the order: drug + vanillin + acid.

\section{Quantification}

In order to investigate the range in which the colored products adhere to Beer's law, the absorbance of the products were measured at $\lambda_{\max }$ value after developing the color by following the suggested procedure for a series of solutions containing increasing amounts of DN or RNZ (Figure 7). The Beer's law limits and molar absorptivity values were evaluated and given in Table 2 , which are indicated that the method is sensitive. The linearity was represented by the regression equation and the corresponding correlation coefficient for drugs determined by the proposed method represents excellent linearity. The relative standard deviation (RSD) and accuracy (average recovery \%) for the analysis of five replicates of each three different concentrations for DN and RNZ indicated that the method is precise and accurate. Limit of detection (LOD) and limit of quantitation (LOQ) were calculated according to the following equations:

$$
\mathrm{LOD}=3.3 \sigma / \mathrm{b} \text { and } \mathrm{LOQ}=10 \sigma / \mathrm{b}
$$

where $\sigma$ is the standard deviation of five reagent blank determinations and $b$ is the slope of the calibration curve. The results obtained are in the accepted range below the lower limit of Beer's law range. 


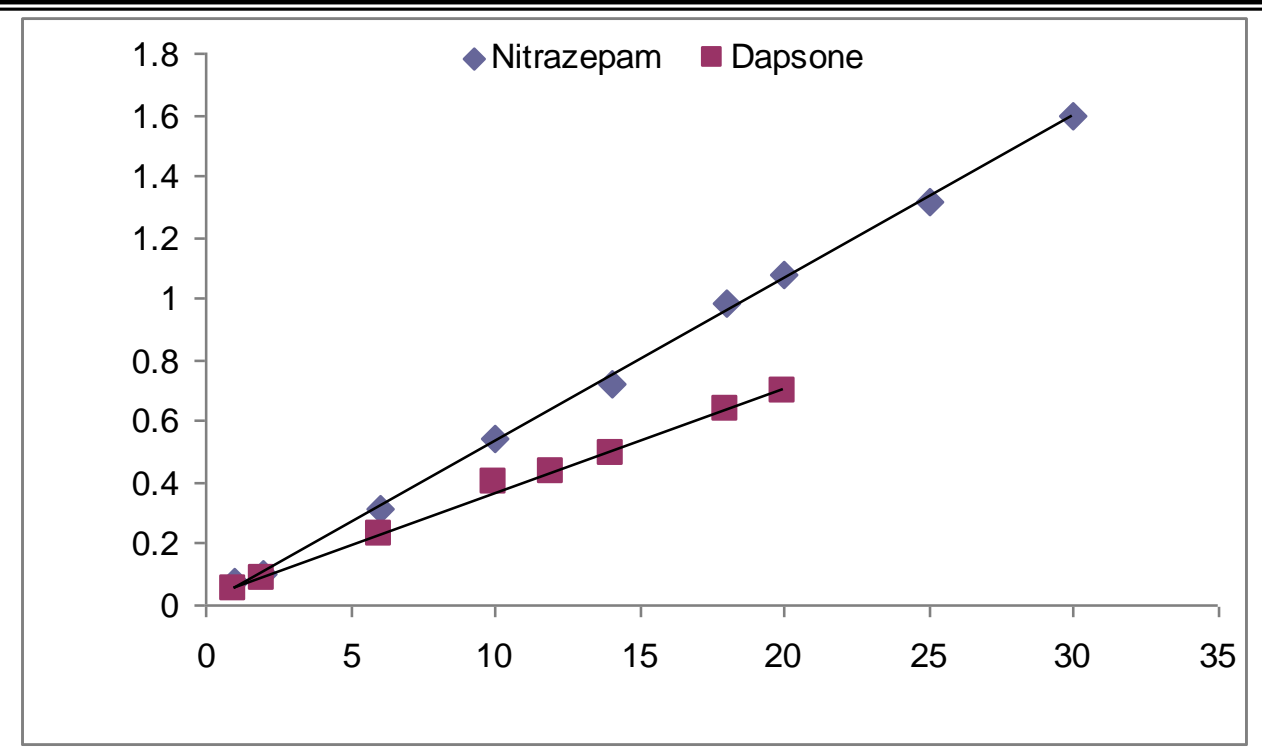

Figure 7: Calibration graph for determination of dapson and nitrazepam drugs

\section{Accuracy and precision}

The accuracy and precision of the method were evaluated by performing five replicate analyses on pure drug solution at three different concentration levels (within the working range). The average recoveries (\%), an indicator of accuracy were $100.31 \%$ and $98.94 \%$ and relative standard deviation (RSD \%), an expression of precision were $\leq 1.57$ and $\leq 0.67$ for $\mathrm{DN}$ and $\mathrm{NZ}$ respectively, indicating high accuracy and repeatability of the method. The results of the study are given in Table 2.

Table 2 : Summary of optical characteristics and statistical data for the proposed method

\begin{tabular}{lcc}
\hline Parameter & DN & RNZ \\
\hline$\lambda_{\max }(\mathrm{nm})$ & 405 & 405 \\
Linear range $\left(\mu \mathrm{g} \cdot \mathrm{ml}^{-1}\right)$ & $1-20$ & $1-30$ \\
Molar absorptivity $\left(1 . \mathrm{mol}^{-1} \cdot \mathrm{cm}^{-1}\right)$ & $8.69 \times 10^{3}$ & $1.332 \times 10^{4}$ \\
LOD $\left(\mu \mathrm{g} \cdot \mathrm{ml}^{-1}\right)$ & 0.087 & 0.069 \\
LOQ $\left(\mu \mathrm{g} \cdot \mathrm{ml}^{-1}\right)$ & 0.299 & 0.231 \\
Average recovery $(\%)^{*}$ & 100.31 & 98.94 \\
Correlation coefficient & 0.996 & 0.999 \\
Regression equation $(Y)^{* *}$ & & \\
Slope, $a$ & 0.035 & 0.053 \\
Intercept, $b$ & 0.023 & 0.004 \\
RSD & $\leq 1.57$ & $\leq 0.67$ \\
\hline
\end{tabular}

* Average of five determinations

** $Y=a X+b$, where $X$ is the concentration of DN and RNZ in $\mu \mathrm{g} \mathrm{ml}^{-1}$. 


\section{Interference}

The extent of interference by some excipients which often accompany pharmaceutical preparations were studied by measuring the absorbance of solutions containing $10 \mu \mathrm{g} \mathrm{ml}^{-1}$ of each DN and RNZ separately, and various amounts of diverse species, up to 20 fold excess, in a final volume of $5 \mathrm{ml}$. It was found that the studied excipients did not interfere seriously, (Table 3).

Table 3: Effect of excipients for assay of DN and RNZ

\begin{tabular}{|c|c|c|c|c|c|c|c|c|}
\hline \multirow{3}{*}{$\begin{array}{l}\text { Foreign } \\
\text { Compound }\end{array}$} & \multicolumn{8}{|c|}{ Recovery \% } \\
\hline & \multicolumn{4}{|c|}{$\begin{array}{c}10 \mu \mathrm{g} \cdot \mathrm{ml}^{-1} \text { of DN per } \mu \mathrm{g} \cdot \mathrm{ml}^{-} \\
{ }^{1} \text { foreign added }\end{array}$} & \multicolumn{4}{|c|}{$\begin{array}{l}10 \mu \mathrm{g} \cdot \mathrm{ml}^{-1} \text { of RNZ per } \mu \mathrm{g} \cdot \mathrm{ml}^{-1} \\
\text { foreign added }\end{array}$} \\
\hline & 20 & 50 & 100 & 200 & 20 & 50 & 100 & 200 \\
\hline Glucose & 100.49 & 102.23 & 103.73 & 103.23 & 97.57 & 100.74 & 101.29 & 102.38 \\
\hline Lactose & 101.49 & 100.75 & 102.73 & 103.73 & 99.43 & 99.25 & 102.99 & 101.12 \\
\hline Arabic Gum & 99.00 & 100.50 & 101.49 & 103.48 & 98.48 & 99.44 & 101.48 & 101.29 \\
\hline $\begin{array}{l}\text { Sodium } \\
\text { Chloride }\end{array}$ & 98.26 & 101.74 & 102 & 104.23 & 97.00 & 96.44 & 99.44 & 98.31 \\
\hline Sucr & 98.76 & 100.25 & 103 & 97.90 & 97.90 & 100.56 & 100.19 & 101.66 \\
\hline Starch & 100.99 & 102.23 & 103.23 & 98.86 & 98.86 & 99.81 & 101.12 & 101.49 \\
\hline
\end{tabular}

\section{Stoichiometry and Stability constant}

The molar ratio of the complexes formed between the DN and RNZ with vanillin reagent were investigated by applying the mole ratio and continuous variation (Job's) methods [31], using equimolar solutions of each $\left(1 \times 10^{-2} \mathrm{M}\right)$. The results indicated that the products were formed in the ratio of $1: 1$ for DN and RNZ to the reagent (Figures 8,9). This finding supports that The $\mathrm{NH}_{2}$ group in $\mathrm{DN}$ or which produced from the reduction of the NZ drug was sharing in the formation of Schiff's base products.
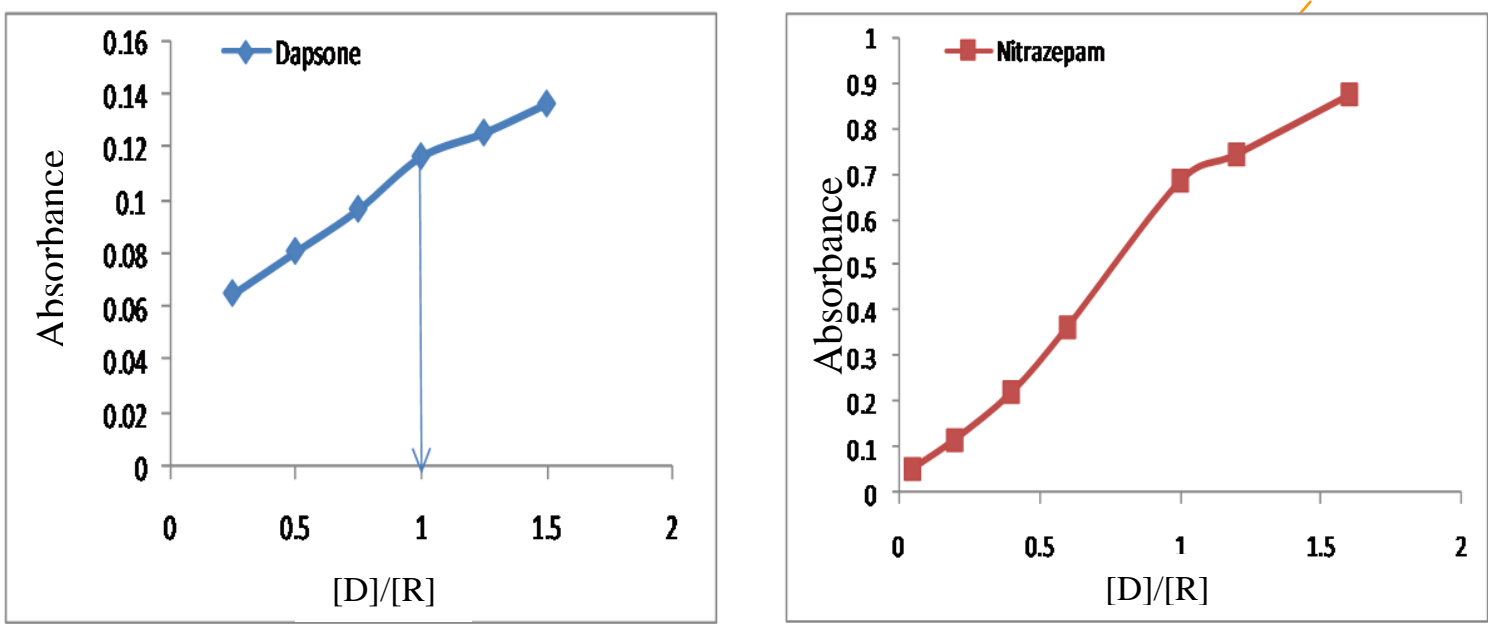

Figure 8: Mole ratio plots for products of $D N$ and $R N Z$ with vanillin reagent under the optimum reaction conditions. 

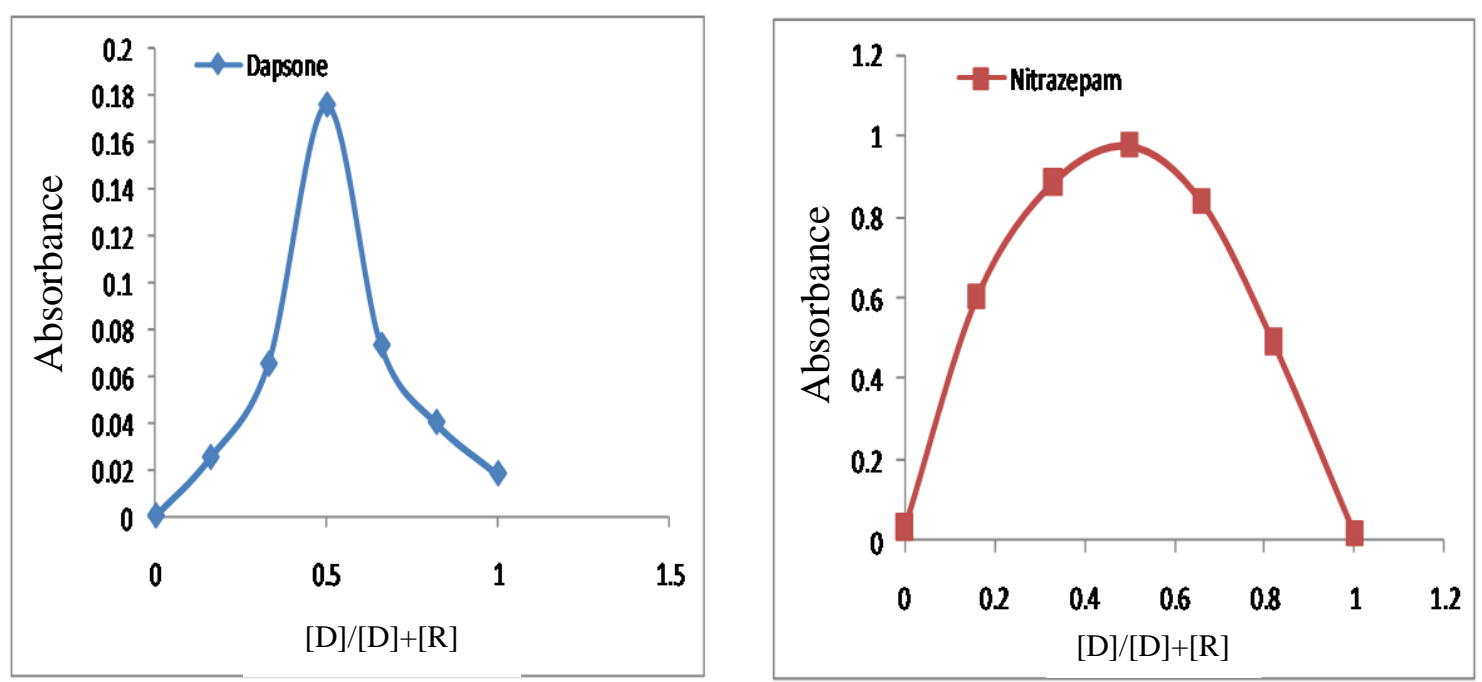

Figure 9: Continuous variation plots for products of DN and RNZ with vanillin reagent under the optimum reaction conditions.

The apparent stability constant was estimated by comparing the absorbance of a solution containing stoichiometric amounts of the drug and vanillin (As) to one containing an excessive amount of vanillin reagent $(\mathrm{Am})$. The average conditional stability constant of the complex was calculated, according to the 1:1 ratio, by the following equation:

$$
\begin{gathered}
\mathrm{Kc}=1-\alpha / \alpha^{2} \mathrm{C} \\
\alpha=\mathrm{Am}-\mathrm{As} / \mathrm{Am}
\end{gathered}
$$

where $\mathrm{Kc}$ is the stability constant $\left(1 . \mathrm{mol}^{-1}\right), \alpha$ the dissociation degree and $\mathrm{C}$ the concentration of the product which is equal to the concentration of drug. However; the average of stability constant for three different concentration was found $1.607 \times 10^{4}$ and $4.631 \times 10^{4} 1 . \mathrm{mol}^{-1}$ for DN and $\mathrm{RNZ}$ respectively indicating the good stabilities.

\section{Analytical applications}

The proposed method was successfully applied to determine DN and NZ in its pharmaceutical preparation as tablet. The obtained results were compared statistically by student's t-test for accuracy and a variance ratio F-test for precision with the official methods [1], which are depending on spectrophotometric method for NZ tablet and potentiometric titration for DN tablet, at $95 \%$ confidence level with six degrees of freedom, as cited in Table 4 . The result showed that the t- test and F-test were less than the theoretical value $(\mathrm{t}=2.57, \mathrm{~F}=5.05)$, indicating that there was no significant difference between the proposed method and official methods. 
Table 4: Assay of DN and RNZ in tablet using the proposed method and comparison with the official methods

\begin{tabular}{|c|c|c|c|c|c|c|c|}
\hline $\begin{array}{l}\text { Procedure } \\
\text { applied }\end{array}$ & $\begin{array}{c}\text { Pharmaceutical } \\
\text { preparation }\end{array}$ & $\begin{array}{c}\text { Drug } \\
\text { amount } \\
\text { present } \\
\left(\mu \mathrm{g} \cdot \mathrm{ml}^{-1}\right)\end{array}$ & $\begin{array}{c}\text { Recovery }^{\mathrm{a}} \\
(\%)\end{array}$ & $\begin{array}{c}\text { Drug } \\
\text { content } \\
\text { found }(\mathrm{mg})\end{array}$ & $\begin{array}{c}\text { Average } \\
\text { recovery } \\
(\mathrm{mg})\end{array}$ & $\begin{array}{l}\text { Certified } \\
\text { value } \\
(\mathrm{mg})\end{array}$ & $\mathrm{RSD}^{\mathrm{a}}$ \\
\hline \multirow{6}{*}{$\begin{array}{l}\text { Proposed } \\
\text { method }\end{array}$} & \multirow{3}{*}{$\begin{array}{l}\text { Dapsone }^{c} \\
\text { Tablet }\end{array}$} & 6.0 & 101.67 & 101.67 & \multirow{3}{*}{$\begin{array}{c}100.54 \\
(0.312,2.6)^{b}\end{array}$} & \multirow{3}{*}{$100 \mathrm{mg}$} & \multirow{3}{*}{1.27} \\
\hline & & 14.0 & 100.41 & 100.41 & & & \\
\hline & & 20.0 & 99.55 & 99.55 & & & \\
\hline & \multirow{3}{*}{$\begin{array}{l}\text { Mogadon }^{\mathrm{d}} \\
\text { Tablet }\end{array}$} & 10.0 & 100.19 & 5.01 & \multirow{3}{*}{$\begin{array}{c}5.01 \\
(0.562,2.9)^{b}\end{array}$} & \multirow{3}{*}{$5 \mathrm{mg}$} & \multirow{3}{*}{0.291} \\
\hline & & 14.0 & 99.21 & 4.96 & & & \\
\hline & & 18.0 & 100.84 & 5.06 & & & \\
\hline \multirow{6}{*}{$\begin{array}{c}\text { British } \\
\text { Pharmacopoeia }\end{array}$} & \multirow{3}{*}{$\begin{array}{l}\text { Dapsone } \\
\text { Tablet }\end{array}$} & \multirow{3}{*}{$250(\mathrm{mg})$} & 99.36 & 99.36 & \multirow{3}{*}{100.06} & \multirow{3}{*}{$100 \mathrm{mg}$} & \multirow{3}{*}{1.24} \\
\hline & & & 101.84 & 101.84 & & & \\
\hline & & & 100.85 & 100.85 & & & \\
\hline & \multirow{3}{*}{$\begin{array}{c}\text { Mogadon } \\
\text { Tablet }\end{array}$} & \multirow{3}{*}{$5(\mathrm{mg})$} & 99 & 4.95 & \multirow{3}{*}{4.97} & \multirow{3}{*}{$5 \mathrm{mg}$} & \multirow{3}{*}{1.37} \\
\hline & & & 101 & 5.05 & & & \\
\hline & & & 98.4 & 4.92 & & & \\
\hline
\end{tabular}

$\mathrm{a}=$ Average of four determinations

$b=$ Figures in parenthesis are the calculated values for $t$ and $F$ tests respectively

$\mathrm{c}=$ Domina pharmaceuticals , Damascus

$\mathrm{d}=$ Marketed by Roche Co. Switzerland

\section{Conclusions}

A simple, sensitive and rapid method is described for the determination of DN and NZ in its dosage forms as tablets. The method is based on the formation of Schiff's base products by reaction of vanillin as a chromogenic agent with DN and RNZ. The method is rapid and applied at ambient temperature, color development is instantaneous and does not require strict $\mathrm{pH}$ control or extraction step. The color formed is highly stable leading to very precise results.

\section{References :}

1) British Pharmacopia on CD-ROM. (2012), General Medical Council, London.

2) Michael J.N., (2002), "Medical Pharmacology at a Glance", 4t Ed, Blackwell Sci, UK.

3) British Pharmacopia on CD-ROM. (2010), General Medical Council, London.

4) http://www.mayoclinic.com/health/drug-informationalDR600515

5) Salama N. N. A., Ries M. A., Toubar S., Hamid M.A. and Walash M. I., (2012), Validated TLC and HPLC stability indicating methods for the quantitative determination of dapsone, J. Plan. Chromatogr. 25, 65-71.

6) Kaklamanos G., Theodoridis G., (2012), Determination of dapsone in mussel tissue and milk using high performance liquid chromatography-tandem mass spectrometry, J. Agric. Food Chem., 60(1), 29-35. 
7) Vieire J. L. F., Riveira J. G. B., Martins A. N. S., Silva J. P., Salgad, (2010), Methemoglobinemia and dapsone levels in patients with leprosy, Braz. J. Infect. Dis., 14(3).

8) Economou A., Petraki O., Tripi D., Botitsi E., (2012), Determination of a liquid chromatography-tandem mass spectrometry method for the determination of sulfonamides, trimethoprim and dapsone in honey and validation according to commission decision, Talanta 15, 32-41.

9) El Ries M. A.., Salama N. N.., Toubar S., El Hamid M. A. and Walash M.I., (2011), Differential pulse anodic voltammetric determination. of dapsone in pharmaceutical preparation using carbon paste and glassay carbon electrodes application to quality control, Sensing in Electroanalysis, 6, 307-321.

10) Jain R., Mishra R., Dwivedi A., (2009), Voltammetric behaviour of nitrazepam in solubilized systems, J. Sci. Ind. Res., 68, 540-547.

11) Raghad S. A., (2010), Spectrophotometric determination of nitrazepam in pharmaceutical tablets using flow injection analysis, J. of University of Anbar for pure science, 4(1).

12) Yang J., Sun M., Fan L., Qiu H., Luo C., (2012), Flow injection chemiluminescence sensor using core-shell molecularly imprinted polymers as recognition element for determination of dapsone, 404, 79-88.

13) Deepakumari H. N., Revanasiddappa H. D., (2013), Spectrophotometric estimation of nitrazepam in pure and in pharmaceutical preparations, J. Spectr., 2013, 1-8.

14) Revanasiddappa H. D., Deepakumari H. N., Mallegouda S. M., Vinay K. B., (2011), Facile spectrophotometric determination of nimodipine and nitrazepam in pharmaceutical preparations, Anal. Univ. D. Bucur.. Chim., 20(2), 189-196.

15) AL-Shaker Y. M., Hasan I. Y., (2011), Spectrophotometric determination of nitrazepam by coupling of diazotized reduced nitrazepam with $\mathrm{N}$-(1-naphthal)ethyl-enediaminedihydrochloride, 22(4), 39-50.

16) Upadhyay K., (2012), Determination of nitrazepam in its pure form, formulations and in biological samples, Recent Research in Science\& Technology, 4(8).

17) Omran AA., (2005), Individual and simultaneous spectrophotometric determination of dapsone and metoclopramide $\mathrm{HCl}$ in pharmaceutical dosage forms and synthetic binary mixtures, 53(11).

18) Daood L. T., (2008), Spectrophotometric determination of dapsone using phloroglucinol azo coupling reagent, Raf. Jour. Sci., 19(3), 24-37.

19) Nagaraja P., Shrestha A. K., Shivakumar A., Gowda A. K., (2010), Use of N,N-diethyl-p-phenylenediamine sulphate for the spectrophotometric determination of some phenolic and amine drugs, Acta Pharm., 60, 217-227. 
20) Hussin M. T., (2010), Spectrophotometric determination of nitrazepam by coupling of its diazotized reduced form with $\mathrm{m}$ aminophenol as coupling reagent, Raf. Jour. Sci., 21(4), 123-140.

21) Revanasiddappa H. D. et al, (2011), Spectrophotometric determination of nitrazepam and nimodipine in pure and the tablet dosage forms, Asian Journal of Biochemical and Pharmaceutical Research, 1, 71-77.

22) Güzel Ö. and Salman A. (2007), Spectrophotometric determination of drugs having primary amine group with pdimethylaminocinnamaldehyde, Turkish J. Pharm. Sci., 4, 31-39.

23) Shoukrallah I, Sakla A and Wintersteiger R., 1990, Spectrophotometric determination of dapsone by using 9chloroacridine as a chromogenic reagent, Pharmazie, 45,675-677.

24) Wang H.Y., $\mathrm{Xu}$ L.X., Xiao Y. and Han J., 2004, Spectrophotometric determination of dapsone in pharmaceutical products using sodium 1,2-naphthoquinone-4-sulfonic as the chromogenic reagent, Spectrochim. Acta A Mol. Biomol. Spectrosc., 60, 2933-2939.

25) Ki H. L. and Dong C. L., 1999. Synthesis and characterization of poly (organophosphazenes) bearing Schiff's base linkages. Polym. Bull. 42, 543-550.

26) Annapurna V., Jyothi G., Rambabu C. and Sailaja B.B.V., 2009. Spectrophotometric determination of ceftiofur hydrochloride using $\mathrm{N}$-bromosuccinimide and p-dimethylaminobenzaldehyde. EJ. Chem. 6, 763-769.

27) Sama N. S., Gurupadayya B.M., and Kumar Ch. A., 2011, Spectrophotometric determination of mesalamine by PDAC and NQS reagents in bulk and tablet dosage form, J. Pharm. Res., 2011, 4(1),39-41.

28) Chaithanya K., Padma A., Swapna A., Rani K.S. and Ramalingam P., 2011, An indirect Spectrophotometric Methods for the estimation of Lamivudine in pure and tablet dosage form, Inter. J. Chem. Tech. Res., 3, 733-736.

29) Klokova E. V. and Dmitrienko S. G., Spectrophotometric determination of sulfanilamides by a condensation reaction with $p$ dimethylaminocinnamaldehyde, Moscow Univ. Chem. Bull., 63, 284- 287, 2008.

30) Adegoke O. A. and Umoh O. E., 2009, A new approach to the spectrophotometric determination of metronidazole and tinidazole using $p$-dimethylaminobenzaldehyde, Acta Pharm. 59, 407- 419.

31) Divad H., (2000), "Modern Analytical Chemistry", McGraw-Hill Higher Edu., USA. 